\title{
Lipase Production by Some Aquatic Phycomycetes in Maiduguri a Semi-Arid Area of Nigeria
}

\author{
Odu, C.E., MSc \\ Department of Biological Sciences, University of Maiduguri, \\ Maiduguri, Nigeria \\ Ogbonna, C.I.C., PhD \\ Applied Microbiology and Biotechnology Research Unit, Dept of Plant \\ Science and Technology,University of Jos, Jos, Nigeria \\ Chukwu,.O.O.C., PhD \\ Molecular Biology Department, FCVMLT, VOM, Jos, Nigeria \\ Onyimba, I.A., PhD \\ Department of Science Laboratory Technology, University of Jos, \\ Jos, Nigeria \\ Ndirmbula, J.B., BSc \\ Department of Crop Protection, University of Maiduguri, \\ Maiduguri, Nigeria
}

doi: 10.19044/esj.2017.v13n27p286 URL:http://dx.doi.org/10.19044/esj.2017.v13n27p286

Abstract

Studies on the abilities of three species of aquatic phycomycetes isolated from the semi arid zone of Nigeria in Maiduguri, Borno State to produce lipase was carried out. The isolates included Allomyces anomalus, Allomyces arbuscular and Brevilegnia diclina. These three test aquatic phycomycetes were isolated using baiting technique with hemp seeds and pure cultures maintained on malt extract agar for lipase production. Plate assay and culture broth assay methods using mineral salts medium with tween 80 in conjunction with Olive oil and Mustard seed oil as lipase inducers were used in assessing the abilities of the isolates in producing lipase. The three isolates of aquatic phycomycetes showed via the plate assay method abilities to produce lipase with evidence of halo formation around colonies without stains and separately with intensification of halo formation with methyl red and sudan III indicators. Allomyces anomalus recorded the highest growth and halo diameter followed by Allomyces arbuscular and least by Brevilegnia diclina. Lipase level was not detectable using the culture broth method. Lipase production by aquatic phycomycetes have not been encountered from available literature, hence this preliminary result needs to 
be optimised fully to exploit new opportunities of lipase production from these group of aquatic fungi

Keywords: Aquatic phycomycetes, Lipase, Olive oil, Mustard seed oil, Tween 80

\section{Introduction}

Lipases are valuable biocatalysts which are widely used in the detergent, food, dairy and pharmaceutical industries. Enzyme lipase hydrolyses the breakdown of triacylglycerols to diacylglycerols and monocylglycerol with free fatty acids as co-products (Beissonet al., 2000).

There are ubiquitous natural sources of lipases, including animals (Gargouriet al., 1986), plants (Kapronchikovet al., 2004 and Fuchs et al., 1996), fungi and bacteria (Gupta et al., 2004). Modern biotechnology has also developed various lipases for application in foods, detergents and pharmaceuticals (Gupta et al., 2004). Fungi are a diverse group of microorganisms ranging from Yeasts and rusts to mushrooms and include many organisms of industrial and medical importance. Aquatic phycomycetes are a group of aquatic fungi that mainly belong to members of Chytridiomycetes and Oomycetes, though mainly aquatic, some species are found on moist soil. Chytridiomycetes and Oomycetes are separated on the basis of flagella being uniflagellate and biflagellate respectively (Khulbi, 2001). Production of enzymes, particularly lipase by aquatic phycomycete have not been encountered in available literature but Some filamentous fungi like several species of Rhizopus have found many applications in industrial processes including enzyme production (Semeriva and Dufour, 1972). Microbial enzymes like lipases are produced by a wide range of microorganisms. Microbial lipase acts on a variety of substrates which have been shown to be hydrolysed by Rhizopus species and other filamentous fungi, these substrates include olive oil, tributyrin, triacetin and polyester molecules (Semeriva and Dufour, 1972; Tokiwa and Suzuki, 1977). Fan et al. (2013) also used optimised mineral salt medium supplemented with olive oil and Tween 80 to increase the lipase activity of Rhizopus stolonifer by 2.04 fold. Apart from lipase producing abilities of Rhizopus species, recently fungal lipases were reviewed and included Aspergillus, Penicillium, Rhizopus, Candida etc (Singh and Mukhopadhyay, 2012). This recent review of fungal lipase are all filamentous fungi, reports of enzyme lipase production by aquatic phycomycetes species have not been captured in reviews of fungi that have the abilities to produce enzyme lipase. Microorganisms have existed on the planet Earth over millions of years and are a source of biotechnological possibilities due to their genetic plasticity and adaptation. The isolation of new species from several and different 
habitats, such as saltwater and freshwater, soils, hot springs, contaminated water bodies, soils, caves and hostile arid environments is therefore required. Microorganisms adapted to these conditions may have great biotechnological potentials (Izabelet al.,2012). This study is about assessing the potentials of aquatic phycomycetes from an unexploited arid zone environment of North Eastern Nigeria to produce enzyme lipase which available literature have not reported coming from these species of fungi.

\section{Materials and methods Sampling sites}

The water samples were collected from three sampling sites in the Maiduguri area of Borno State namely Alau dam, River Ngadda by Cocacola company area and River Ngadda by Lagos bridge. Maiduguri is the capital city of Borno State located in the north- east geopolitical zone of Nigeria and shares borders with Niger, Cameroon and Chad.

\section{Water Sample Collection, Transportation And Storage}

Water sample from experimental sampling sites (Alau dam, River Ngadda by Coca-cola area and River Ngadda by Lagos bridge) were collected in sterile $100 \mathrm{mls}$ and $200 \mathrm{mls}$ bottles at the littoral zones (shorelines) of these water bodies in the month of April, 2017. The sampling bottles were opened inside the water and immediately capped before bringing them out of the water to avoid contamination. All collected water samples were labelled with different code for analysis purpose. Water samples were then transported to the laboratory in Biological Sciences department of University of Maiduguri, in a plastic cooler with ice packs maintained at a temperature of $4^{\circ} \mathrm{c}$ and were analysed as soon as practicable on the day of collection between 2-6 hours.

\section{Isolation and identification of aquatic phycomycetes}

Aquatic phycomycetes species were isolated from the water samples collected from the three sampling sites above using hemp seeds (Cannabis sativa) as bait as used by Marano et. al., (2008) and Nascimentol et. al., (2011). Observations of growth of the baited aquatic phycomycetes were made for four to seven days and in some cases for up to 2 weeks. Colonies appearing on baited seeds were separated based on closely observed morphological differences like colour, length of the hyphae, concentration of hyphae around the seed and in conclusion differentiation into species was based on morphological differences of zoosporangia and hyphae. Baited seeds with aquatic phycomycetes isolated showing similar morphological characteristic were pulled together into Petri dishes containing sterile distilled water to which anti-biotic had been added to suppress bacteria 
growth and observed directly under the compound light microscope for identification (Trifa and Adiba, (2011),. Marano et. al., (2008) and Nascimentol et. al., (2011), alternatively, observation of a pin head of hyphae stained with lactophenol cotton blue was also made under a compound light microscope to support identification. Result as seen from the microscope under appropriate magnification were then compared for similarity with pictures and description found in the manual for identification of aquatic phycomycetes by Khulbi, (2001) and to existing stock cultures in some Nigerian Universities laboratory and also Ali, (2007). Three aquatic phycomycetes isolates baited on hemp seeds separated based on observed morphological characteristics and purified in sterile distilled water had their hyphae point inoculated onto malt extract agar medium and subsequently maintained as pure culture. Four day old pure cultures of the three isolates were used for the preliminary assay of enzyme lipase by plate method and liquid broth method using tween 80 in conjunction with olive oil and mustard seed oil as inducers. The three test aquatic phycomycetes isolates included Allomyces anomalus isolated from River Ngadda by Lagos bridge, Allomyces arbuscular isolated from River Ngadda by Coca-cola area and Brevilegnia declina isolated from Alau dam, all in Maiduguri metropolis of Borno State.

\section{Enzyme lipase plate assay}

The mineral salt media (MSM) used for the enzyme lipase plate assay was prepared according to the composition used by Maria et al., (2015) and was composed of Peptone $10 \mathrm{~g}$, Sodium Chloride (Nacl) 5g, Hydrated calcium chloride $\left(\mathrm{CaCl}_{2} .2 \mathrm{H}_{2} \mathrm{O}\right) 0.1 \mathrm{~g}$, Agar powder $16 \mathrm{~g}$ and Distilled water $1000 \mathrm{ml}$. The mineral salt medium (MSM) prepared above was sterilized in a laboratory auto clave at $121{ }^{\circ} \mathrm{C}$ for 15 minutes and was divided into $100 \mathrm{ml}$ amounts and supplemented with separately sterilized tween 80 in conjunction with olive oil and mustard seed as follows; Control mineral salt medium without incorporation of tween 80 , olive oil or mustard seed oil, $1 \%$ olive oil MSM - $100 \mathrm{ml}$ of MSM supplemented with $1 \mathrm{ml}$ olive oil and $0.5 \mathrm{ml}$ tween $80,1 \%$ mustard seed oil MSM- $100 \mathrm{ml}$ of MSM was supplemented with $1 \mathrm{ml}$ of mustard seed oil and $0.5 \mathrm{ml}$ of tween 80 . Olive oil, mustard seed oil and tween 80 were separately sterilized gradually with Millipore filter paper before incorporation into the mineral salt medium.

Each of the three four day old test aquatic phycomycetes were grown separately on the three different mineral salt medium incorporated with tween 80 in conjunction with either olive oil or mustard seed oil by centrally inoculating the hyphae with an inoculating needle and incubated at $28{ }^{\circ} \mathrm{C}$ and observed for growth and development of halo. A clear zone (Halo) around the colony indicated lipase -positive aquatic phycomycetes. The second set 
of experiment incorporated two indicators (stains) as used by Mohammed et al., (1988) to intensify the clear zone or halo formed by the isolates. Drops of the stains, methly red and sudan III reagent were separately incorporated into the MSM media supplemented with olive oil and mustard seed oil before point inoculation of the three test aquatic phycomycetes isolates and incubated at $28{ }^{0} \mathrm{C}$ and also observed daily for growth and halo development. A clear zone around the colony also indicated lipase positive aquatic phycomycetes isolates.

\section{Enzyme lipase broth assay}

Production of enzyme lipase using nutrient broth supplemented separately with olive oil and mustard seed and both seeded with tween 80 was also carried out according to the method of Sumathy et al., (2012). Nutrient broth was prepared according to manufacturers instruction and $50 \mathrm{mls}$ was dispensed into sets of $100 \mathrm{ml}$ conical flasks and stopped with cotton wool and aluminium foil. $0.5 \mathrm{ml}(1 \%)$ of tween 80 was added to each of the conical flasks containing $50 \mathrm{mls}$ of nutrient broth except the control conical flask. The conical flasks with the nutrient broth and tween 80 were then divided into two sets. One set was supplemented with $1 \%$ olive oil while the second set was supplemented with $1 \%$ mustard seed oil while the control without tween 80 was not supplemented with either olive oil or mustard seed oil. The nutrient broth supplemented with tween 80 and either olive oil and mustard seed oil and the control conical flask were then separately inoculated with four day old culture of the three test aquatic phycomycetes isolates and properly covered with cotton wool and aluminium foil. The culture broths were then incubated at $28{ }^{0} \mathrm{C}$ for seven days.

\section{Enzyme extraction and purification}

The seven days old culture broths were then used for enzyme extraction, purification and assay of lipase activity. The culture broth was centrifuged at $6,000 \mathrm{rpm}$ at $4^{0} \mathrm{C}$ for 40 minutes. The supernatant was collected from the culture broth and subjected to cold acetone precipitation. Finally the protein pellet was dissolved in proper buffer $(20 \mathrm{mM}$ Tris-Hcl buffer, pH 7.2)

\section{Assay of Lipase activity}

Lipase activity was estimated by titrimetric assay

Units/ml of enzyme $=$ Final burette reading $\mathrm{X}$ Normality of $\mathrm{NaoH}$ $\mathrm{X}$ Time of Incubation $\mathrm{X}$ Dilution factor 


\section{Result}

\section{Occurrence and selection of test aquatic phycomycetes}

Ten species of aquatic phycomycetes were isolated from the three sampling sites and they included Allomyces anomalus, Allomyces arburscular, Allomyces recurvus, Brevilegnia diclina, Saprolegnia bhargavi, Saprolengnia ferax, Protoachyla oryzae, Protoachyla paradoxa, Blastocladiela variabilis and Aphanomyces helicoides but three isolates were selected based on their highest frequency of occurrence in each of the three sampling sites. Allomyces anomalus selected from River Ngadda by Lagos bridge are shown as micrographs in Plates 4 and 5. The Plates 4 and 5 shows fertile terminal hyphae and irregular surface captured on microscopic slide stained with lactophenol blue. The micrographs of Allomyces anomalus also shows abundant resting sporangia capable of producing zoospores after rest. Plate 5 also shows almost at the left hand base of the micrograph, a fertile terminal branch showing globular zoosporangia. Allomyces arbuscular isolated from River Ngadda by Coca-cola area as shown in microgaph of Plate 6 reveals a dichotomously branched and pseudoseptate hyphae. Brevilegnia declina isolated from Alau dam in Maiduguri is shown in Plate 7 as terminal matured zoosporangium with liberation of zoospores. Alau dam is the source of water treatment for supply of portable water to the inhabitants of Maiduguri.

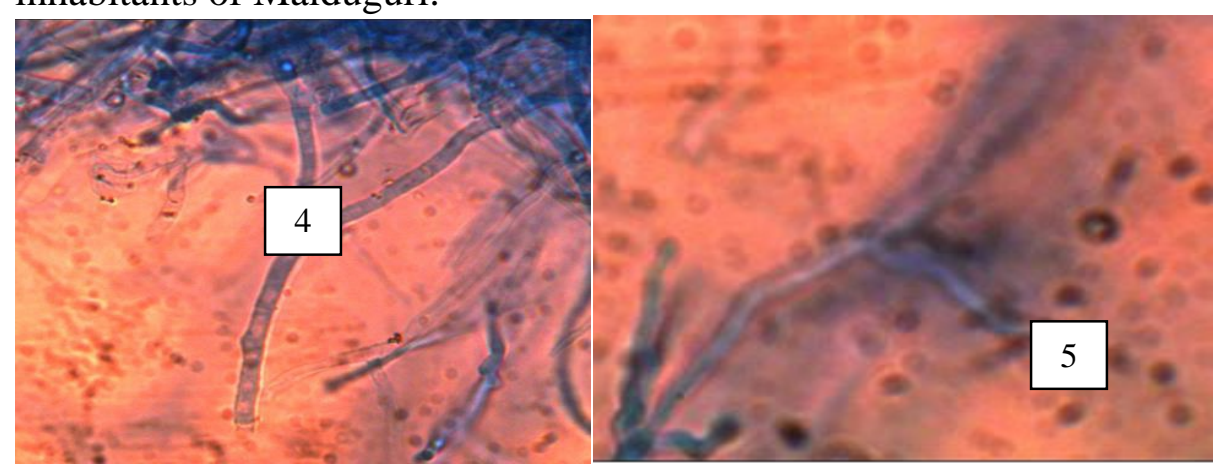

Plate 4 :Allomyces anomalus (x10x40) showing fertile terminal branching of hyphae and irregular surface captured on microscope slide stained with lactophenol cotton blue

Plate 5: Allomyces anomalus (x10x40) showing fertile terminal branching of hyphae, irregular surface and resting abundant sporangia captured on microscope slide stained with lactophenol cotton blue. 


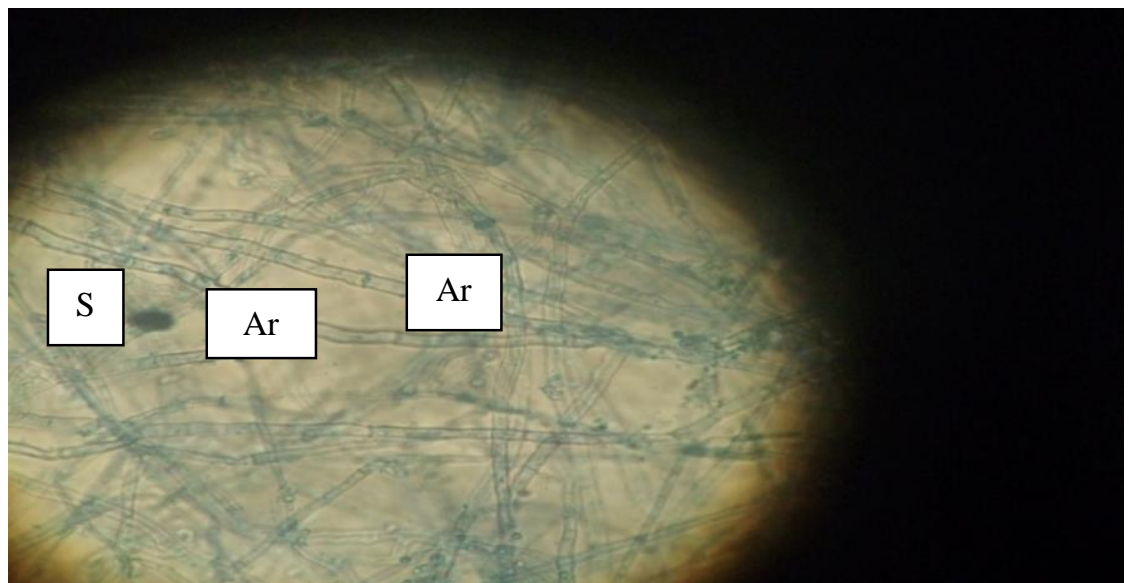

Plate 6: Micrograph of Allomyces arbuscular (Ar) (x10x40) showing branching pattern of hyphae, thick walled resting sporangium $(\mathrm{S})$ and pseudoseptate hyphae.

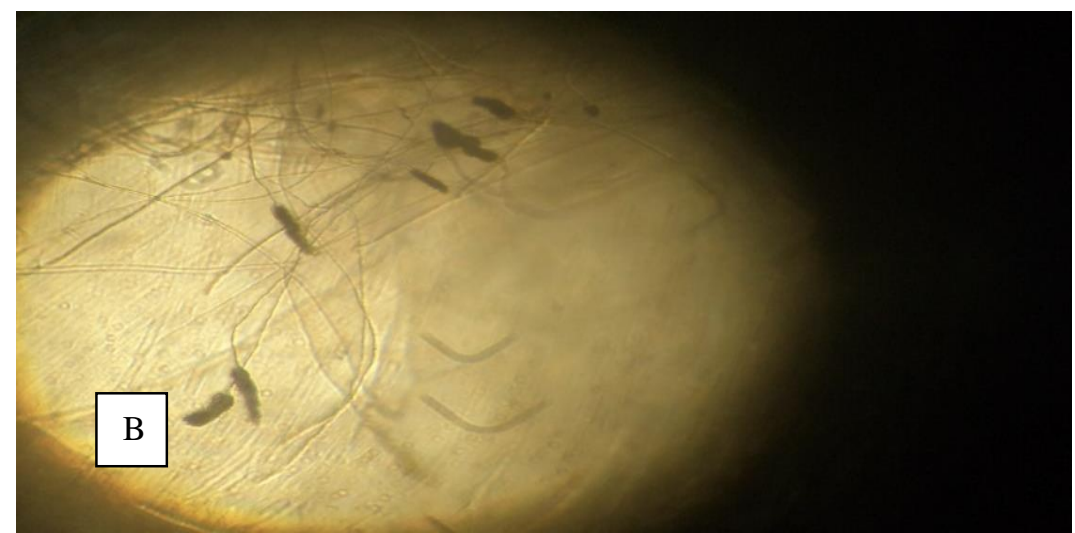

Plate 7: Micrograph of Brevilegnia diclina (B) (x10x40) showing terminal matured zoosporangium with liberation of zoospores

\section{Enzyme lipase production by aquatic phycomycetes via plate assay without stain}

The result of abilities of three species of aquatic phycomycetes to produce enzyme lipase using plate assay without stains showed clearly positive results with visible halo surrounding the colonies of all the test species of aquatic phycomycetes. These halo (clear zone around colony) however showed little or no observable difference. The control experiment of the three test species was negative for halo formation. Table1 shows the highest colony diameter for Allomyces anomalus grown on MSM supplemented with mustard seed $(29.5 \mathrm{~mm})$ with a slightly higher halo diameter of $2.0 \mathrm{~mm}$. Same Table 1 shows that Allomyces anomalus grown on MSM supplemented with olive oil had the next highest colony diameter of 27.5 with a halo diameter of $1.5 \mathrm{~mm}$. Allomyces anomalus showing clear zone around colonies of isolates grown on MSM supplemented with olive oil 
and mustard seed oil are shown in Plate 8. Allomyces arbuscular showed colony diameters of $23.5 \mathrm{~mm}$ and $24.2 \mathrm{~mm}$ with corresponding halo diameters of $1.5 \mathrm{~mm}$ each for growth on MSM supplemented with olive oil and mustard seed oil respectively. Plate 9 also shows clear zone as halo around the colony of Allomyces arbuscular indicating enzyme lipase production. Brevilegnia diclina showed the least colony diameters of $20.2 \mathrm{~mm}$ and $20.0 \mathrm{~mm}$ with a corresponding halo diameter of $1.0 \mathrm{~mm}$ for growth on MSM supplemented with mustard seed oil and olive oil respectively.

\section{Enzyme lipase production by aquatic phycomycetes via plate assay with} stain

The result of the experiment on the abilities of species of aquatic phycomycetes to produce enzyme lipase via plate method to intensify enzyme production with two stains methyl red and sudan III reagent showed methyl red stain intensifying halo formation for Allomyces anomalus grown on MSM supplemented with mustard seed oil as shown in Table 2. Table 2, also shows halo produced by Allomyces arbuscular supplemented with mustard seed oil intensified by sudan III reagent while Brevilegnia diclina grown on MSM supplemented with Olive oil also had its halo intensified by methyl red stain as also shown in Table 2. Table 2 also confirms production of enzyme lipase with evidence of halo or clear zone formation around some of the colonies grown on MSM supplemented with two enzyme lipase inducers namely olive oil and mustard seed oil, However, the halo diameters did not show clear observable differences in terms of diameter measurements.

Table 1: Enzyme lipase production by aquatic phycomycetesvia plate assay without stain

\begin{tabular}{|c|c|c|c|c|c|}
\hline $\begin{array}{c}\text { Test aquatic } \\
\text { phycomycetes }\end{array}$ & Inducer & $\begin{array}{c}\text { Conc of } \\
\text { inducer } \\
(\mathrm{ml})\end{array}$ & $\begin{array}{l}\text { Conc of } \\
\text { surfactant } \\
\text { tween } 80 \\
(\mathrm{ml})\end{array}$ & $\begin{array}{l}\text { Colony } \\
\text { diameter } \\
(\mathrm{mm})\end{array}$ & $\begin{array}{c}\text { Halo } \\
\text { diameter } \\
(\mathrm{mm})\end{array}$ \\
\hline \multirow{2}{*}{$\begin{array}{l}\text { Isolate A } \\
\text { Allomyces } \\
\text { anomalus }\end{array}$} & Olive oil & 1.0 & 0.5 & 27.5 & 1.5 \\
\hline & $\begin{array}{l}\text { Mustard } \\
\text { seed oil }\end{array}$ & 1.0 & 0.5 & 29.5 & 2.0 \\
\hline \multirow{3}{*}{$\begin{array}{c}\text { Isolate B } \\
\text { Allomyce } \\
\text { sarbuscular }\end{array}$} & Olive oil & & & 23.3 & 1.5 \\
\hline & & 1.0 & 0.5 & & \\
\hline & $\begin{array}{c}\text { Mustard } \\
\text { seed oil }\end{array}$ & 1.0 & 0.5 & 24.2 & 1.5 \\
\hline \multirow{3}{*}{$\begin{array}{l}\text { Isolate C } \\
\text { Brevilegnia } \\
\quad \text { diclina }\end{array}$} & Olive oil & & & 20.0 & 1.0 \\
\hline & & 1.0 & 0.5 & & \\
\hline & $\begin{array}{l}\text { Mustard } \\
\text { seed oil }\end{array}$ & 1.0 & 0.5 & 20.2 & 1.0 \\
\hline Isolates A, B \& & Olive oil & 0.0 & 0.0 & 25.5 & 0 \\
\hline
\end{tabular}




\begin{tabular}{cccccc}
\hline $\mathrm{C}$ (mean) & $\begin{array}{c}\text { Mustard } \\
\text { seed }\end{array}$ & 0.0 & 0.0 & 26.0 & 0 \\
\hline
\end{tabular}

Table 2: Halo/colony diameter of aquatic phycomycete enzyme lipase plate assay with stains (methylred stain and sudan III reagent)

\begin{tabular}{ccccc}
\hline Isolate & Inducer & $\begin{array}{c}\text { Stain or } \\
\text { indicator }\end{array}$ & $\begin{array}{c}\text { Colony } \\
\text { diameter }(\mathrm{mm})\end{array}$ & $\begin{array}{c}\text { Halo diameter } \\
(\mathrm{mm})\end{array}$ \\
\hline $\begin{array}{c}\text { Allomyces } \\
\text { anomalus }\end{array}$ & Olive & Methyl red & - & - \\
Allomyces & Mustard & Methyl red & 62 & 2.0 \\
arbuscular & Olive & Methyl red & - & - \\
Brevilegnia & Mustard & Sudan III & 14.8 & 1.5 \\
declina & Olive & Methyl red & 2.1 & 1.5 \\
Control (mean) & Mustard & Methyl red & - & - \\
\hline
\end{tabular}

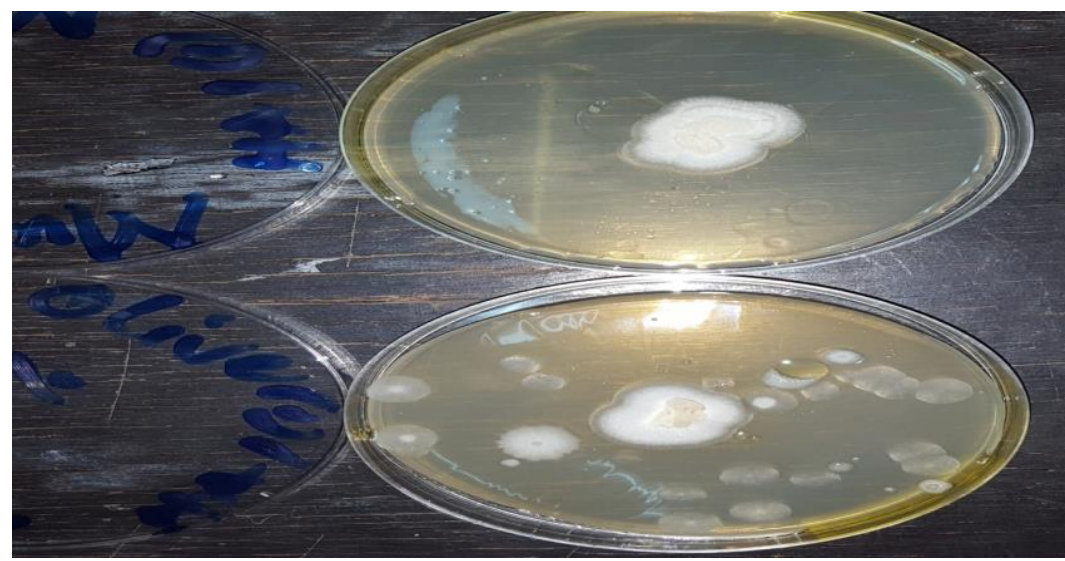

Plate 8: Enzyme lipase produced by Allomyces anomalus as halo on olive and mustard seed oil MSM without stain

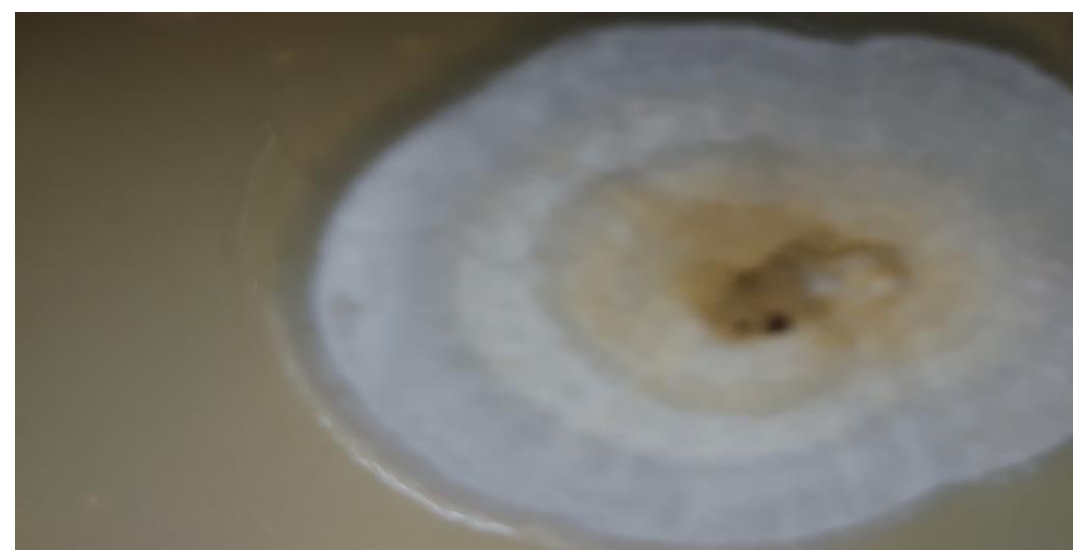

Plate 9: Enzyme lipase produced by Allomyces arbuscular as halo on mustard seed oil MSM without stain 


\section{Enzyme lipase production by aquatic phycomycetes via liquid broth method}

Since enzyme lipase is usually produced extracellularly, the extraction was considered successfully completed by the centrifugation of the culture broth. The purpose of the cold acetone precipitation was to purify the enzyme lipase produced.

The result of the growth of test species of aquatic phycomycetes isolates after seven days in broth culture did not show fungal mycelia mat but rather a colloidal appearance of the culture broth.

The result of enzyme lipase production via broth culture determined by titrimetric method were all inconclusive since detectable levels of enzyme lipase was not recorded as shown in Table 3.

Table 3 : Enzyme lipase production by aquatic phycomycetes via liquid broth assay

\begin{tabular}{cccc}
\hline $\begin{array}{c}\text { Test aquatic } \\
\text { phycomycetes } \\
\text { isolates }\end{array}$ & Inducers & $\begin{array}{c}\text { Concentration of } \\
\text { inducer }(\%)\end{array}$ & $\begin{array}{c}\text { Titrimetric values } \\
\text { (unit/ml) }\end{array}$ \\
\hline Allomyces anomalus & Olive oil & $1 \%$ & In conclusive (nil) \\
Allomyce sarbuscular & Mustard seed oil & $1 \%$ & In conclusive \\
& Olive oil & $1 \%$ & Inconclusive \\
Brevilegnia declina & Mustard seed oil & $1 \%$ & Inconclusive \\
& Olive oil & $1 \%$ & Inconclusive \\
& Mustard seed oil & $1 \%$ & inconclusive \\
\hline
\end{tabular}

Note: inconclusive means that no detectable level of enzyme lipase was observed.

\section{Discussion}

Enzyme lipase has found a wide industrial application for the past two decades. The isolation of lipase by sources such as plants and animals are cost effective and yield is also very less. Due to this low yield of the enzyme from plants and animals sources, attention have been focused on microbial enzymes. Of all microbes, fungal strains are preferred for lipase production since their enzymes are secreted extracellularly which makes extraction technique easy. Production of enzyme lipase by the group of water fungi known as aquatic phycomycetes is rare or even nonexistent from available literature. Hence the result obtained from this research effort is discussed in the light of production of enzyme lipase by fungi particularly filamentous fungi. Literature on production of enzyme lipase by filamentous fungi (e.g Aspergillus, Penicillium, Rhizopus and Candida spp) abounds due to the high economic value of this very important enzyme (Singh and Mukhopadhyay, 2012). Aquatic phycomycetes occurrence have not been reported in published literature from the war ravaged arid zone North Eastern Nigeria, it is therefore novel that a variety of aquatic phycomycetes were isolated from three fresh water bodies in Maiduguri. Three of these isolates namely Allomyces anomalus, Allomyces arbuscular and Brevilegnia diclina occurred commonly in these freshwater bodies in Maiduguri and were used 
as test organisms for their abilities to produce enzyme lipase. In line with this study that found amongst others, the occurrence of three aquatic phycomycetes in the harsh arid zone freshwater environment of Maiduguri, North eastern Nigeria, aquatic phycomycetes are found throughout the world according to a review by Shearer et al. (2007). In Nigeria, Alabi (1971) investigated the distribution of Saprolegniaceae in Ibadan (Western part of Nigeria), while many ecological studies of aquatic phycomycetes have been studied worldwide (Willoughby, 1974; Steiow, 1998; Maranoet al.,2008). Some studies have equally confirmed them as parasites of fish. Czeczuga et al. (2002) found that some of these species may be potential source of infection and are able to grow and cause infection on muscles of fish and their eggs. In Nigeria, Ogbonna and Alabi (1991) also worked on fungi associated with mycotic infection of fish and isolated twenty four (24) species belonging to six genera of aquatic phycomycetes from infected fishes. Thus similar species of aquatic phycomycetes from this study have been isolated in Nigeria but no study has been recorded with aquatic phycomycetes on their abilities to produce enzymes or enzyme lipase in particular. The results of this study showed that the three test isolates of aquatic phycomycetes were able to produce enzyme lipase in the preliminary studies using plate assay method and two inducers, olive oil and mustard seed oil. The tween 80 incorporated is a surfactant which increases the surface contact between substrate and organism. The three test aquatic phycomycetes namely Allomyces anomalus, Allomyces arbuscular and Brevilegnia diclina showed clear halos around their colonies as evidence of enzyme lipase production but there were no great observable differences in the diameter of the halo produced by the three isolates even though Allomyces anomalus seemed to have recorded the highest colony diameter and slightly higher halo diameter. In line with the result of this study, Fan et al. (2013) used an optimized medium for lipase production in Rhizopus stolonifer which had some mineral salts with olive oil and tween 80 at the same time. They reported that the optimized medium increased the lipase activity nearly two fold from 0.46 to $1.40 \mu / \mathrm{ml}$. Tween 80 was used in these study to achieve better stimulation of enzyme lipase in aquatic phycomycetes as was used by Fan et al.(2013). In line with the results of this study Mohammed et al.(1988) used tween 80 as substrate with different stains or indicators including Victoria blue and Methyl red as indicator. They determined lipolytic activity using a method of plate assay as used in this study by observing the formation of the zone of intensification of the indicator colour after 24 hours. Allomyces anomalus in this study produced enzyme lipase with evidence of halo around the colony which was intensified by Methyl red indicator which proved better than the Sudan III reagent. 
The study of enzyme lipase production in broth culture could not yield a detectable level of enzyme lipase from aquatic phycomycetes using titrimetric method. This is as opposed to similar study by Sumathy et al. (2012) who produced lipase activity from three filamentous fungi, Aspergillus niger, Rhizopus oryzae and Fusarium oxysporium using three enzyme lipase inducers in broth culture namely Olive oil, Gingerly oil and Mustard seed oil. They found that Aspergillus niger with Olive oil as inducer produced the maximum lipase activity as compared with other strains and concluded from their results that the concentration of the inducers used for the study did not affect the production of lipase. Even though Sumathy et al.(2012) concluded that the filamentous fungi produced lipase efficiently in the chosen inexpensive substrates as used in this study, they also stated that several other factors like temperature, $\mathrm{pH}$, fermentation method, environmental factors, etc, may also affect the enzyme production. In line with these, it is worthy to note that the mineral salts used in this study were different from those used by Sumathy et al.(2012). It is therefore very important to analyse the above stated parameters in detail to optimize the lipase production by commonly available fungal strains. Thus further research may be needed that will incorporate some other factors in assaying for enzyme lipase production by culture broth method particularly considering the arid zone environmental factor of Maiduguri, North eastern Nigeria with its attendant high temperature regimen. Sabiha and Jadhav (2013) studied lipase production of some fungal species and their application in oil spillage degradation. They studied the role of three lipolytic fungal species (Aspergillus niger, Aspergillus paraciticus and Aspergillus aculeatus) activity on various oil spillages ( Soyabean, Mustard and Coconut oil) degradation. Their result revealed that all three fungal strains were able to degrade Soyabeans, mustard and coconut oil and they affirmed that the lipolytic fungi have ability to degrade other oil spillage and hydrocarbons as also supported by Kavitha et al. (1997). This is in line with the result of this research effort which equally showed that three species of aquatic phycomycetes were able to produce enzyme lipase by evidence of halo production when grown on mineral salt medium supplemented with two lipase inducers namely Olive oil and Mustard seed oil.

\section{Conclusion}

The implication of these findings is that since these aquatic phycomycetes were isolated from polluted freshwater environment (River Ngadda by Lagos bridge and Cocacola areas of Maiduguri in particular), they have the abilities to degrade pollutants like vegetable oils and oil of hydrocarbon origin from automobile washing and domestic activities within the water bodies and in degrading these oils, they also have abilities to 
produce enzyme lipase that breaks the oil to fatty acids and glycerol as simpler subunits. Aquatic phycomycetes species should therefore be further surveyed in future work for their role in biodegradation of oil pollutants and commercial production of enzyme lipase.

\section{References:}

1. Alabi, R.O. (1971). Seasonal periodicity of Saprolegniaceae at Ibadan, Nigeria. Transaction of British Mycological Society 56: 337341.

2. Ali, E.H. (2007). Biodiversity of zoosporic fungi in polluted water drainages across Niles Delta region, Lower Egypt. Acta Mycologica 42(1): 99-111.

3. Beisson, F., Tiss, A., Riviere, C. and Verger,R. (2000). Methods for lipase detection and assays: a critical review. European Journal of Lipid Science and Technology, 102, 133-153.

4. Czeczuga, B., Kizicwicz, B. and Danilklewicz, Z. (2002). Zoosporic fungi growing on the specimens of certain fish species recently introduced to polish water. Actaichthyologica ETPiscatoria 32(2): 117-125

5. Fan, Y., Shang, L. and Qian, J. (2013). Screening, identifying and medium optimization of a lipase-producing filamentous fungus from soil for high chiral resolution of 1-phenylethanol. African Journal of Microbiology Research. 7(33); 4235-4243.

6. Fuchs, C., Vine, N. and Hills, M.J. (1996). Purification and characterization of the acid lipase from the endosperm of castor oil seeds. Journal of Plant Physiology. 149,23-29.

7. Gargouri, Y., Pieroni, G., Riviere, C., Sauniere, J.F., Lowe, P.A., Sarda, L. and Verger,R. (1986). Kinetic assay of human gastric lipase on short and long chain triacylglycerol emulsions. Gastroenterology. 91, 919-925.

8. Gupta, R., Gupta, N. and Rathi, P. (2004). An overview of production and biochemical properties of enzyme lipase. Applied Microbiology and Biotechnology. 64, 763-781.

9. Izabel Soares, Zacarias Távora, Rodrigo Patera Barcelos and Suzymeire Baroni (2012). Microorganism- Produced Enzymes in the Food Industry, Scientific, Health and Social Aspects of the Food Industry, Dr. Benjamin Valdez (Ed.), ISBN: 978-953-307-916-5, InTech, Available from:http://www.intechopen.com/books/scientifichealth-and-social-aspects-of-the-food-industry/microorganismproduced- enzymes-in-the-food-industry

10. Kapronchikov, V.S., Zheresbtsov, N.A., and Popova, T.N. (2004). Purification and characterisation of lipase from wheat (Triticum 
aestivum L.) germ. Applied Biochemistry and Microbiology. 40, 98103.

11. Kavitha, N.S.A., Hilda, G.S. and Latha, K. (1997). Hydrolysis of oils and marine environmental ethics by Rhodamine method, Biomanagement of Biogeoresources, 16-19.

12. Khulbe, R.D. (2001). A manual of aquatic fungi (chytridiomycetes and Oomycetes). Daya publishing house, Delhi. 255pp.

13. Marano, A.V., Barrera, M.D., Steiow, M.M., Donadelli,J.L. and Saparrat, C.M.N, (2008). Frequency, abundance and distribution of zoosporic organisms from Las Canas stream (Buenos Aires, Argentina) Mycologia 100:691-700.

14. Maria, G.I., Sridhar, K.R. and Raviraja, N.S. (2015). Antimicrobial and enzyme activity of mangroove endophytic fungi of South-West coast of India. Journal of Agricultural Technology. 1, 67.

15. Mohammed, Y.A., Samad, C.,Nyonya, A. Rasak., Abubakar Salleh, W.M., Zin, Wan Yunus., Kamaruzaman Ampon and Mahiran Basri (1988). A plate assay for primary screening of lipase activity. Journal of Microbiological methods. 9, 51-56.

16. Nascimentol, C. A., Eduardo, P. C. G. and Pires-Zottarelli, C. L. A. (2011). Occurrence and distribution of zoosporic organisms in water bodies from Brazilian cerrado. Mycologia 103(2): 261-272.

17. Ogbonna, C.I.C. and Alabi, R.O. (1991). Studies on species of fungi associated with mycotic infections of fish in a Nigerian fresh water fish pond. Hydrobiologia 220:131-135.

18. Sabiha, N. and Jadhav, S.K. (2013). Studies of the estimation of lipase production capability of some fungal species and their application in oil spillage degradation. International Journal of Science and Research, 2319-7064.

19. Semeriwa, M. and Dufour, C. (1972). Further studies on the exocellular lipase of Rhizopus arrhizus. Biochemica et Biophysica Acta. 260, 393-400.

20. Shearer, C.A., Enrique, D., Brightte, K., Kohhmeyer,J., Marvanova,L., Padget, D., Porter, D., Raja, H.A., Schmit, J.P., Thorton, H.A. and Voglymayr,H. (2007). Fungal biodiversity in Aquatic habitat. Biodiversity conservation 16:49-67.

21. Singh, A.K. and Mukhopadhyay, M. (2012). Overview of fungal lipase: A review . Applied Biochemistry and Biotechnology. 166, 486-520.

22. Steciow, M.M. (1998). Variacionestacionalde los Oomycetes em um ambientecontaminado: Rio santiago Y affluentes (Buenos Aires, Argentina). Rev iberoammicol 15; 40-43. 
23. Sumathy, R., Vijayalakshmi, M. and Deecaraman, M. (2012). Studies on lipase production fromfungal strains by different inducers at varied concentrations. A comparative study. International Journal of Environmental Science. 3(3) 1072-1078.

24. Tokiwa, Y. and Suzuki, T. (1977). Hydrolysis of polyesters by lipase. Nature 270. 76-78.

25. Trifa, K. F.andAdiba, S.A.(2011). An ecological study on the occurrence and distribution of aquatic fungi in Sarchnar water spring within Sulaimani province, Kurdistan region of Iraq. Journal of AlNahrainUniversity 14(4) 137-145.

26. Willoughby, L.G. (1974). Decomposition of litter in freshwaters. in; Dickinson, C.H, Pugh G.T.F,(Eds). Biology of plant litter decomposition. vol 10. London; Academic press, p 659-681. 